https://doi.org/10.31470/2706-7904-2021-16-274-278

\title{
MODERN EDUCATIONAL COMPONENTS OF INNOVATION TEACHING \\ OF FOREIGN LANGUAGE IN THE ESTABLISHMENTS OF HIGHER EDUCATION
}

Сучасні освітні компоненти інноваційного навчання іноземної мови у закладах вищиӧ освіти

\author{
Svitlana Tanana \\ Ph.D. in Pedagogy, Assistant Professor \\ Hryhorii Skovoroda University in Pereiaslav (Ukraine) \\ tananasvetlana@gmail.com \\ https://orcid.org/0000-0002-6088-0738
}

\begin{abstract}
The article deals with the theoretical aspects of the problem of readiness for the innovative activity, its analyze the modern components of the professional competence and innovative activity. Professional development of future teacher of philological subjects process is complicated and lengthy. Theoretical and practical study is necessary part during of future teacher's master of system or research knowledge in the branch of philological subjects in conjunction with general professional training. The problem of using of interactive methods in the preparation of teacher-philologists of higher school is considered in the article.
\end{abstract}

Keywords: innovation technologies, effectiveness of studies, study of foreign language, professional preparation, future teachers of foreign languages, establishment of higher education.

\section{Introduction} Bcmyn

The globalization and integration country, of world association and European community contributes of to the rapid growth of the role of quality education for the further development of society, and in accordance its intensive reform. Given this problem actualized improve the quality of process of preparation the future teachers, including of future teachers of English for increase their competitiveness, its requires of process to effective realization of competence approach. Effective deciding of these tasks possible for conditions by the improvement of educational content and its procedural-methodical using 
on innovation basis. The quality of professional preparation of future teachers depends of the content to modern education, it should include of full orientation on purchase by students' of system the competencies and permanent updating by improving the mechanisms and their using in everyday practice (Tanana and other, 2021).

The democratic and humanization reforms which take place in Ukraine need renovating the process of teaching foreign languages, re-comprehending aims, tasks and contents of education, implementation of new educational technologies to master foreign communicative competence successfully.

Purpose of the research is to briefly look at certain of the new methods that have attracted the attention of the profession in recent years, to show reason for interest in them, in what they are exploring, in what they accomplish, the principles and ideas that guide them.

The problem of using the innovation methods of teaching foreign languages at the higher educational establishments were also studied by R. Blair, S. Martinelli, L. Konoplianyk, O. Siutkina, H. Stern, Ye. Polat, M. Tailor and other.

\section{Methods and techniques of the research Методи і методики дослідження}

The methodological basis of the research is general scientific methodological provisions, theory of cultural linguistics, communication studies, intercultural communications, and complex approach to the material: axiological, cultural.

\section{Results}

\section{Результати}

Strategy of innovations teaching used in the educational process of higher institutions is connected with the using of new technologies. Interactive training as a new methodological approach to the foreign language teaching gives a chance to solve communicative-cognitive tasks through foreign language communication (Zarichanska, 2017: 47). Interactive teaching is this kind of learning and cognition activity, which is realized in the form of a dialogue (student, teacher, student-student) with continuous adjustment of the learning content according to the analysis of activity of the subject of teaching. From conditions of using of interactive methods in the teaching process is organized, that almost all the students are involved in the learning process. The purpose of interactive methods in the process of learning a foreign language is to create of learning conditions in which all students' interaction among ourselves. 
So, in terms of methodology, the meaning of category innovation learning will be considered as: a) a dialogue training in the course of which interaction between a teacher and a student occurs; b) training the purpose of which tackles linguistic, communicative and action tasks. Interactive training activity involves the organization and development of dialogue speech aimed at mutual understanding, interaction, solving of modern and general but significant tasks for every participant of the educational process (Dubaseniuk, 2019).

The main principles of cooperative learning within the innovation teaching system are:

(1) positive interdependence - when each student performs his (her) job well, the group succeeds;

(2) individual responsibility - when working together in a group each student has a different job;

(3) equal participation - each student is given the same amount of time to speak or complete a task;

(4) simultaneous interaction - when all students are involved at the same time (Kozak, 2019). In the process of dialogue teaching the students learn: to solve complex problems on the basis of analyzing the circumstances and corresponding information, to consider alternative opinions, to take well-considered decisions, to take part in discussions, to associate with different people.

It's necessary to organize different forms of activity at the foreign language group that is individual, pair, and team. Among the most well known form of pair and group work the following kinds should be mentioned: inside (outside) circles, brain storm, line-ups, jigsaw reading, think-pair-share, debate, pair-interviews etc. E.g., jigsaw reading is an activity which involves the splitting of a text into different parts or the use of different texts on the same topic. The parts are given to different learners to read. They must communicate with each other in order to find out the whole message or different views on the topic.

It is necessary to point out that all above-mentioned form of interactive training is efficient in case a problem is discussed as a whole in the students have previous experience and ideas which they have acquired earlier at their classes or in a course of their private life. In the process of work the teacher should take into consideration the fact that the topics which are to be discussed in the classroom must not be limited or very narrow. One of the most common peculiarities which are characteristic of the interactive forms are those that these forms of training motivate the student not only to express their own opinion but after some argumentation of their partners in the process of work to change the point of view (Tanana, 2021).

The following advantages of strategy of innovation learning are determined: friendly atmosphere and relationships between learners are formed; learners have the opportunity to be more independent and self-confident; they are not afraid to make mistakes; it'll help the learners 
to overcome the problems of language barrier confidence and fear of making mistakes; learners talking time is longer, it's good for communication; a teacher doesn't dominate; a teacher has an opportunity to give the task to every student. All learners are involved in the work; it's good for individual work; learners can use their background knowledge.

The language is the social product, and as the form of existence of human intellectual activity it embraces all spheres of individual and social life. Perhaps one of the most essential pedagogical principles of language teaching is one that emphasizes the study of language in a cultural context. One of the main tasks of teaching foreign languages is the penetration into the culture the peoples whose language is learnt, into the system of their world perception. The language is the result of theoretical and practical activity of both an individual and society. The culture of peoples, social conditions of life and the language are inseparably connected.

The priority of education development at the University Hryhoriy Skovoroda in Pereiaslav is the implementation of modern information technologies that provide the access to the network of high quality databases, widen the possibility of students to apprehend complex information. It is realized through the construction of individual module teaching programs with various complexity levels depending on specific needs, the use of the interactive methods, introduction of remote education, production of electronic textbooks.

\section{Conclusions}

Висновки

So, modern components of innovation teaching of foreign language give us a chance to solve some problems simultaneously. The main purpose is to develop communicative skills, to help establish emotional contact with the student, provide with realization of educational task, that is: to train them to work in a team, to considered somebody's opinion. As seen from experience the use of the above mentioned methods helps to avoid a student's nervous tension, to change the forms of activity, to draw attention to the main question of the lesson (Gunko, 2017).

\section{References \\ Jimepamypa}

Dubaseniuk, O.A. (2019). Introduction of educational innovations in the system of higher education. Innovations in higher education: problems, experience, prospects. Zhytomyr: Ivan Franko State University Publishing House.

Gunko, N.A. (2017). Modern information and educational environment as a factor in improving the professional and pedagogical training of future teachers. Scientific notes of TNPU, 3, 43-48. 
Kaminskaya, A.V. Formation of readiness of future teachers for innovative activity in a higher educational institution. Retrieved from http://nvd.luguniv.edu.ua/archiv/NN13/11kavvnz.pdf

Kozak, L.V. (2019). Innovative teaching as a basis for the development of innovative personality of the future teacher. Development of personality in the conditions of transformational society: materials of the International scientific-practical conference. (Kyiv, December 13) (p. 36-42). Kyiv: Borys Hrinchenko Kyiv University.

Tanana, S.M., Khmelnytska, O.S., Bahno, Y.M., Serhiychuk, O.M., \& Tkachenko, L.V. (2021). Features of Pedagogical Practice in the Process of Professional Training of a Future Teacher. Geintec. Gestao, Inovacao e Tecnologias, 2049-2065.

Tanana, S.M., Khmelnytska, O.S., Bahno, Y.M., Serhiychuk, O.M., \& Tkachenko L.V. (2021). Formation of Linguistic Competence of a Foreign Teacher (On The Example of Language). May/Aug. Conhecimento cientifico: certezas e incertezas, 518-527.

Zarichanska, N.V. (2017). The use of innovative technologies in the educational process: methodical recommendations. Vinnitsa. VDPU. 